\title{
Phytoextraction from Chromium-Contaminated Soil Using Moso Bamboo in Mediterranean Conditions
}

\author{
Ezio Ranieri $[$ - Angelo Tursi • Silvia Giuliano • \\ Vincenzo Spagnolo • Ada Cristina Ranieri • Andrea \\ Petrella
}

Received: 3 April 2020 / Accepted: 13 July 2020 / Published online: 26 July 2020

(C) The Author(s) 2020

\begin{abstract}
An experimentation has been carried out in simulated Mediterranean and tropical laboratory conditions aimed to show the Moso bamboo capability of phytoextraction chromium from contaminated soil. Electronic microscopy supported the analyses performed on soil and on the different plant tissues. A preliminary test on the bamboo has been carried out in laboratory evaluating his growth with irrigation in Mediterranean conditions (600 mm/year) and tropical conditions $(1.800 \mathrm{~mm} /$ year). A test of the bamboo tolerance of was also carried out by measuring his growth with irrigation with a solution of $100 \mathrm{mg} \mathrm{Cr} / \mathrm{l}$, reporting not significant damages to the plant tissues. Subsequently chromium phytoextraction was tested highlighting that bamboo removes $\mathrm{Cr}$ from soil with a percentage ranging from $43 \%$ (600 mm/year) to $47.4 \%$ (1.800 mm/year) of the total content in soil. Lastly, the distribution of chromium in the different fragments of the bamboo plants has been performed. It has been shown that approx. 69\% of chromium, in Mediterranean conditions, was in the rhizomes and approx. $68 \%$ in tropical conditions. A
\end{abstract}

E. Ranieri $(\bowtie) \cdot$ A. Tursi $\cdot$ S. Giuliano

Dipartimento di Biologia, Università degli Studi di Bari, Bari, Italy e-mail: ezio.ranieri@uniba.it

V. Spagnolo

Dipartimento di Fisica, Politecnico di Bari, Bari, Italy

A. C. Ranieri

Faculty of Engineering, Uninettuno University, Rome, Italy

A. Petrella

Dicatech, Politecnico di Bari, Bari, Italy slightly higher tendency to chromium translocation to leaves has been shown in tropical conditions than in Mediterranean conditions.

Keywords Bamboo growth · Tolerance $\cdot$ Chromium removal $\cdot$ Metals translocation

\section{Introduction}

Phytoremediation can be applied both in the presence of inorganic contaminants, such as heavy metals, through extraction or stabilization processes, and in the presence of organic contaminants, through degradation or extraction processes (Gardea-Torresdey et al. 2004; Anderson et al. 2005; Karimi et al. 2009; Ranieri et al. 2013; Petrella et al. 2016; Ranieri et al. 2020). Phytoextraction, which can be defined as the use of plants to remove non-degradable contaminants from the soil, is considered a green technology that can be applied to some heavy metals (McGrath et al. 2006; Reeves and Baker 2009; Tangahu et al. 2011; Petrella et al. 2012; Gikas and Ranieri 2014; AlBataina et al. 2016; Petrella et al. 2016a, b; Petrella et al. 2018). This remediation is applied in situ, and therefore, it does not require any excavation, transport, and disposal of soil; its main aim is to maintain, restore, or even improve the physical-chemical properties of the soil. Furthermore, it is advantageous both from an ecological point of view, due to its environmental value, and from the economic one, since the costs are much lower than those required for conventional techniques (Ranieri and Swietlik 2010; Van Lienden 2010; Ciudin et al. 2014; Ragazzi et al. 2014). 
The premise of this method is to find out a hyperaccumulator, like Moso bamboo, which has a great ability to accumulate the metals at high biomass production so that it can use his plant's ability of uptake metals which are essential for its growth (Cho-Ruk et al. 2006; Robinson et al. 2006; Arshad et al. 2008; Bian et al. 2017).

Chromium is one of the most common heavy metals in soils and easily adsorbed by plants where is present on a combination of both $\mathrm{Cr}$ (III) and $\mathrm{Cr}(\mathrm{VI})$ (Kabata-Pendias and Pendias 2001). To date, few plants have been identified that can be defined as hyperaccumulators of chromium. Bamboo species usually thrive in toxic environments with minimal maintenance and produce a large amount of biomass (Kigomo 2007). Cr speciation in the plant roots and shoots was found as trivalent chromium $\mathrm{Cr}$ (III) which formed as a result of $\mathrm{Cr}(\mathrm{VI})$ reduction. Under those conditions, there is also a possibility of oxidation of trivalent chromium (Cr(III)) to the more toxic hexavalent chromium Cr(VI) (Vaiopoulou and Gikas 2012; Vaiopoulou and Gikas 2020). But, as predominant mechanism, the Cr(VI) in cells is readily reduced to $\mathrm{Cr}$ (III) which is easily retained in the root cortex cells under low concentration of $\mathrm{Cr}(\mathrm{VI})$ which can explain the higher concentrations of $\mathrm{Cr}$ (III) in plant tissues (Shanker Aruna et al. 2005; Vidayanti et al. 2017).

In the present study, the use of Moso bamboo (Phyllostachys pubescens, Fig. 1) for phytoremediation is investigated in order to:

- Evaluate its growth capacity in a habitat other than that in which it normally develops

- Evaluate the tolerance of the bamboo in chromium contaminated soils

- Evaluate its phytoextraction capacity of chromium

- Assess the migration capacity of the chromium within the plant

To pursue the aforementioned objectives, an experimental study was carried out, conducted in the laboratory and developed in several stages. The first phase, lasting 84 days, had as its objective to compare the development of Moso bamboo in a habitat other than that particularly favorable to its growth (Song et al. 2013), characterized by a tropical or subtropical climate, with the development in a typical Mediterranean climate.

The length was monitored, checking week by week the growth rate of the main morphological parts such as stem and leaves. The second phase, lasting also 84 days,

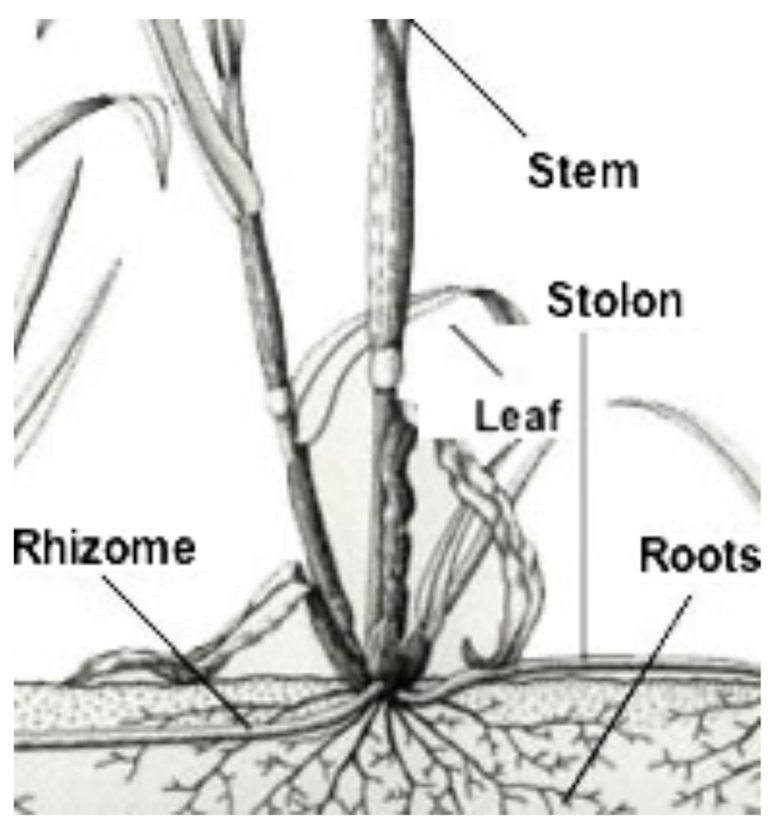

Fig. 1 Scheme of bamboo elements (adapted from Mississippi Watershed 2014 and Agriculture and Natural Resources, University of California, 2019)

was aimed to evaluate the tolerance of Moso bamboo by measuring the growth in a soil contaminated by a chromium solution. The elongations suffered by the main morphological structures were noted weekly, thus allowing the calculation of the growth rate under stress.

During the last 84 days third phase, it was evaluated the chromium transferred from contaminated soil to the plants. Accumulation zones of the chromium in the plant were identified and it was reported a mass balance.

\section{Material and Methods}

The experimental part of this work was carried out entirely in a controlled environment.

The Moso bamboo plants (Fig. 2) are allocated in four pots, for the experiments of adaptability tests, contamination tests, evaluation of chromium removal from soils and roots, rhizomes, stems, and leaves analyses.

Each pot has a diameter $D=25 \mathrm{~cm}$ and height $h=$ $20 \mathrm{~cm}$. Horizontal surface for each pot is equal to $490 \mathrm{~cm}^{2}$, for a single volume of $10 \mathrm{~L}$. The soil was a mixture of blond, brown peat, natural vegetable conditioner, and rich in humified organic substance with density (D) of the soil equal to $0.25 \mathrm{~kg} / \mathrm{l}$. C(org) in the soil is approx. $20 \%$ dry weight (DW) and $\mathrm{N}$ is approx. $1 \% \mathrm{DW}$; $\mathrm{pH}$ was 6.9. The total soil mass per pot was $4 \mathrm{~kg}$. 


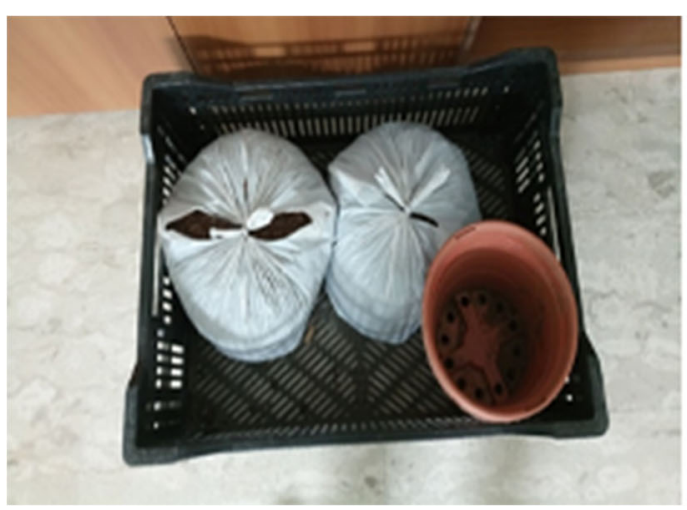

Fig. 2 Soil and pots used during the experimentation

Tap water was used throughout the first two steps of the experimentation, having the following chemical characteristics: bicarbonate $270 \mathrm{mg} / \mathrm{L}$; potassium $27.7 \mathrm{mg} / \mathrm{L}$; calcium $30.9 \mathrm{mg} / \mathrm{L}$; magnesium $9.5 \mathrm{mg} / \mathrm{L}$; fluorides $1 \mathrm{mg} / \mathrm{L}$; nitrate $8 \mathrm{mg} / \mathrm{L}$ as $\mathrm{N}$, and phosphate $1.2 \mathrm{mg} / \mathrm{L}$ as $\mathrm{P}$.

The quantity of water for each plant was calculated based on the rainfall regime and the diameter of the vessel of the sample considered. It was initially thought to follow two rainfall regimes: $1800 \mathrm{~mm} /$ year, a value close to that which is found in the natural habitat of Moso bamboo, and $600 \mathrm{~mm} /$ year, a rainfall regime close to that which is had on average in Apulia. Consequently, two flows (Q) for growth and contamination test were used: $600 \mathrm{~mm} /$ year and $1800 \mathrm{~mm} /$ year that correspond to $\mathrm{Q}_{1}=1.648 \mathrm{~mm} /$ day $=$ $0.0805 \mathrm{l} / \mathrm{day}$ and $\mathrm{Q}_{2}=4.944 \mathrm{~mm} /$ day $=0.2416 \mathrm{l} /$ day .

A scanning electronic microscope (SEM), Sigma 300 $\mathrm{VP}$, at high resolution was used for having support on which sections of Moso bamboo plant were higher the chromium concentration by detecting small lumps adhered to soil particles or tissues forming a heterogenous agglomerate (Figs. 3, 4). In the second step, tap water was added with chromium by a solution of $\mathrm{K}_{2} \mathrm{Cr}_{2} \mathrm{O}_{7}$ apt to form a solution of $100 \mathrm{mg} \mathrm{Cr} / \mathrm{L}$.

\subsection{Bamboo Growth Performance Measurement}

Heights of four pots containing the bamboo species were measured with a ruler to evaluate growth performance each week. For each measurement, a computeraided drawing was updated reporting the distance covered by a single element, cluster or group of stems of bamboo growing from a common underground rhizome system. Any evidence of malformation in plant growth was also annotated.
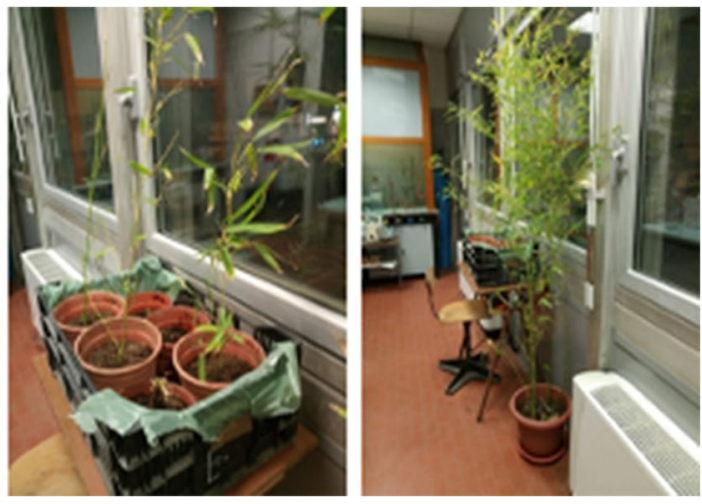

\subsection{Samples Preparation}

Soil samples were air-dried at $75{ }^{\circ} \mathrm{C}$ to a constant weight. The samples were mixed homogeneously and, then, sieved through a 2-mm sieve to remove coarse particles prior to chemical digestion. Each bamboo plant was separated into respective organs composed of roots, rhizomes, stems and leaves. They were then washed in water and rinsed thoroughly with deionized water in order to remove soil particles and debris. The plant materials were subsequently splitted into small pieces and the samples were dried at $75{ }^{\circ} \mathrm{C}$ to a constant weight. They were then milled in a cyclone to a particle size of $0.2 \mathrm{~mm}$. The samples were allocated in desiccators prior to chemical digestion.

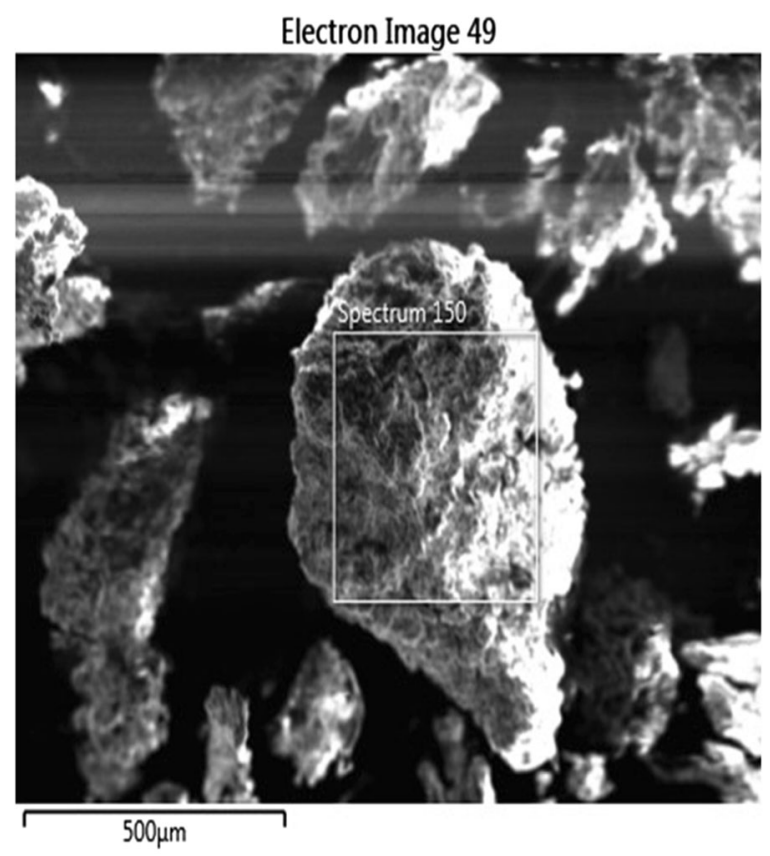

Fig. 3 Soil particles at SEM with presence of chromium 


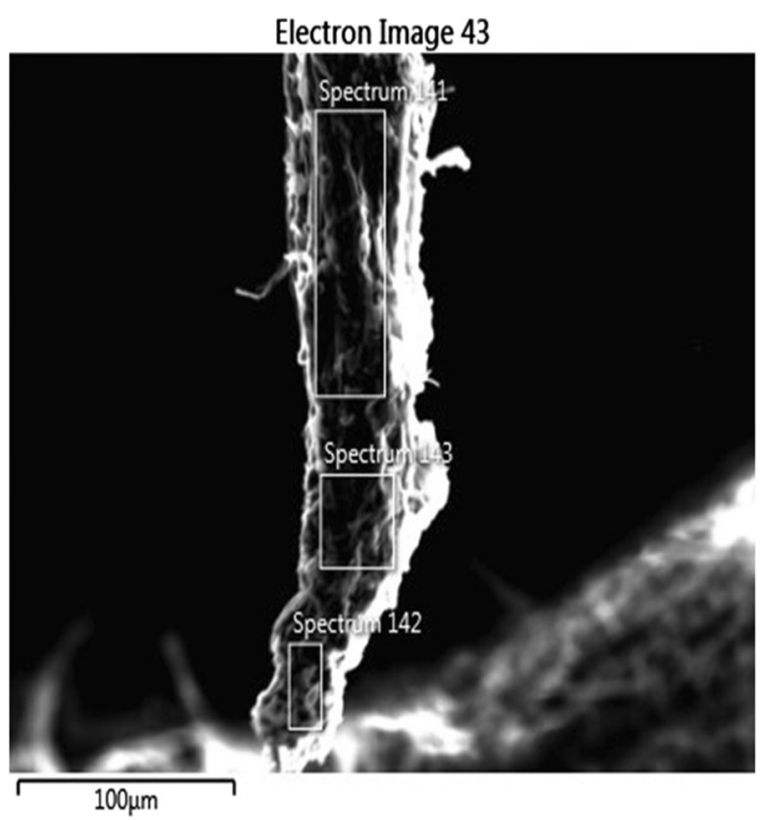

Fig. 4 Rhizomes at SEM with presence of chromium

\subsection{Chemical Digestion of Plant Materials and Soil Samples}

A sample of $0.5 \mathrm{~g}$ of plant materials was digested using $7 \mathrm{~mL}$ of concentrated nitric acid (HNO3): $1 \mathrm{~mL}$ hydrochloric acid (HCI) $(7: 1)$ in a fluorocarbon polymer (PFA/TFM) closed system oven. The vessel liner was equipped with an extraction fume system. The oven unit was equipped with a quartz power system $(1800 \mathrm{~W})$. After cooling the vessel, the clear liquid was diluted to $50 \mathrm{~mL}$ in acid-washed vials.

Dried ground soil samples of $1.5 \mathrm{~g}$ were transferred to the $100-\mathrm{mL}$ digesting tubes. This was followed by addition of aqua regia, a mixture of $20 \mathrm{~mL}$ concentrated $\mathrm{HNO}_{3}$ and $\mathrm{HCl}, 70 \%$ in a ratio of $1: 4$. The tubes were covered by a funnel and digestion at $160^{\circ} \mathrm{C}$ was carried out in a fume chamber using a digestion block. This was heated until about $4 \mathrm{~mL}$ was left in the tube. The procedure was repeated by adding a further $20 \mathrm{~mL}$ of aqua regia and allowed to evaporate to a volume of about $5 \mathrm{~mL}$. Then, the solution was filtered through membrane filters $(10 \mu \mathrm{m})$. The filtrate was then made up to a volume of $25 \mathrm{~mL}$ with de-ionized and distilled water prior to analysis of total $\mathrm{Cr}$. All the digested samples including the laboratory blanks were then taken for the spectroscopic analysis to determine the levels of total $\mathrm{Cr}$. Light and atmospheric moisture were regulated and constants; air temperature was constant and equal to $20^{\circ} \mathrm{C}$ during the experiments.

\subsection{Analysis of Total Chromium Levels}

The plant materials, soil, and blank samples were analyzed for levels of total $\mathrm{Cr}$ using inductively coupled plasma optical emission spectrometry (ICP-OES). Total $\mathrm{Cr}$ levels were therefore determined in the soils before transplanting bamboo species, and those of the corresponding rhizosphere soils, roots, rhizomes, stems and leaves after 6 months of growth period. The levels were expressed in milligram per kilogram of dry weight (mg/kg DW) for each sample.

\subsection{Quality Assurance and Control}

Samples were analyzed using adequate quality assurances and controls (QA/QC) to determine the reliability and accuracy of the results. Precautions were taken to avoid external contamination of the samples. All reagents used throughout the analytical procedure were of high purity analytical grade. Glassware was soaked in $0.5 \%(\mathrm{v} / \mathrm{v})$ of $\mathrm{HNO}_{3}$ and rinsed several times with distilled and de-ionized water prior to use.

\subsection{Statistical Analysis}

The samples were analyzed in triplicate, and the data obtained was then reported as mean \pm standard deviation. One-way and two-way analysis of variance (ANOVA) at $P<0.05$ was used to compare variables between and within the groups using $F$ test for statistical significance.

\section{Results and Discussion}

\subsection{Growth Rate Test on Moso Bamboo}

Given the climatic differences of Moso bamboo, compared to those that represent its optimum for growth, it was necessary to proceed with adaptation tests prior to start the growth test.

The growth test lasted 84 days and was carried out in a laboratory-controlled environment in which the following parameters were constantly monitored:

- Soil pH

- Exposure to light

- Homogeneity of the quantity of water to be supplied in all pots

- Temperature 
Fig. 5 Moso bamboo growth with $600 \mathrm{~mm} /$ year tap water. Pots $1-2$

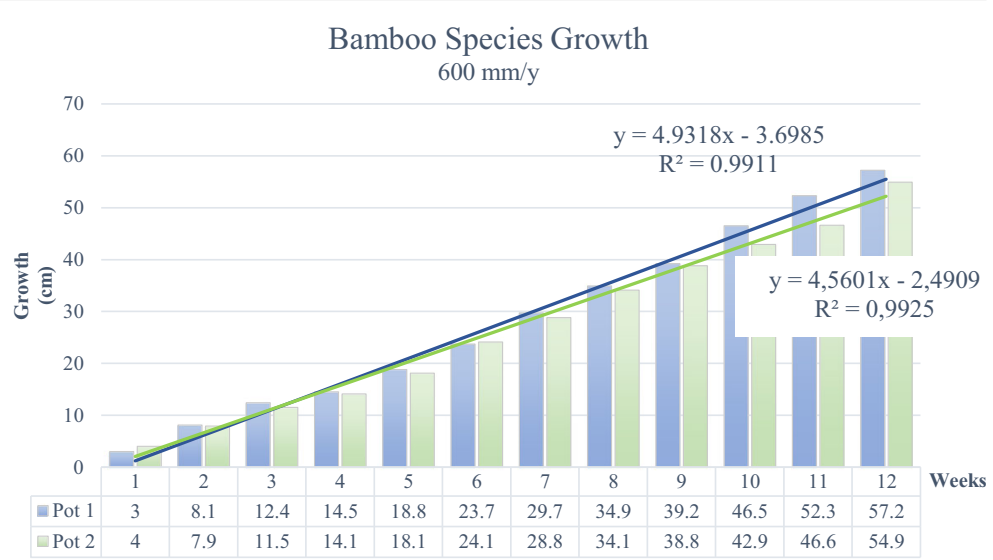

By measuring weekly the variations in length, it was possible to calculate the growth rate $\left(\mathrm{g}_{\mathrm{r}}\right)$, understood as the rate of growth that the morphological parts considered, branches, and total length, had. Results are shown in Fig. 5 for pots 1-2 and in Fig. 6 for pots 3-4. In both cases, bamboo plants showed a good adaptability. The growth rate $g_{r}$ was very similar for pots $1-2(600 \mathrm{~mm} /$ year) and equal to $4.56 \mathrm{~mm} /$ week; also for pots 3 and 4 (1800 mm/year), $g_{\mathrm{r}}$ was equal to almost the double and precisely equal to $8.45 \mathrm{~mm} /$ week as average. The interpolation curve was linear in both cases: $\mathrm{h}=4.56$ (weeks) -2.49 for pots 1 and 2 with $R^{2}=0.9911$ and $\mathrm{h}=$ 8.45 (weeks) -7.39 for pots 3 and 4 with $R^{2}=0.9925$. The total elongation appears to be lower than the one observed in natural conditions (Xu et al. 2011).

Figure 7 presents the height of bamboo plants after the growth rate test.

\subsection{Contamination and Tolerance Test}

The treatment with the contaminant lasted about 3 months according to the concentration of the contaminant solution. Moso bamboo will not survive in metalcontaminated soils with more than $300 \mathrm{mg} \mathrm{kg}^{-1} \mathrm{DW}$ (Chen et al. 2015a). Were et al. (2017) report that the bamboo species had a survival rate of $100 \%$ for all the species grown for soil concentration around $100 \mathrm{mg} \mathrm{Cr} /$ $\mathrm{kg}$ DW. Otherwise, low metal exposure $\left(<100 \mathrm{mg} \mathrm{kg}^{-1}\right.$ DW) does not inhibited plant growth in pots experiment (Michaud et al. 2008; Collin et al. 2013; Chen et al. 2015a, b; Liu et al. 2015). So it is supposed that Moso bamboo should tolerate an higher metal stress, and there is a potentiality to use Moso bamboo as phytoremediation material for Cr-contaminated soil up to $200-300 \mathrm{mg} \mathrm{Cr} / \mathrm{kg} \mathrm{DW}$.
Fig. 6 Moso bamboo growth with $1800 \mathrm{~mm} /$ year tap water. Pots 3-4

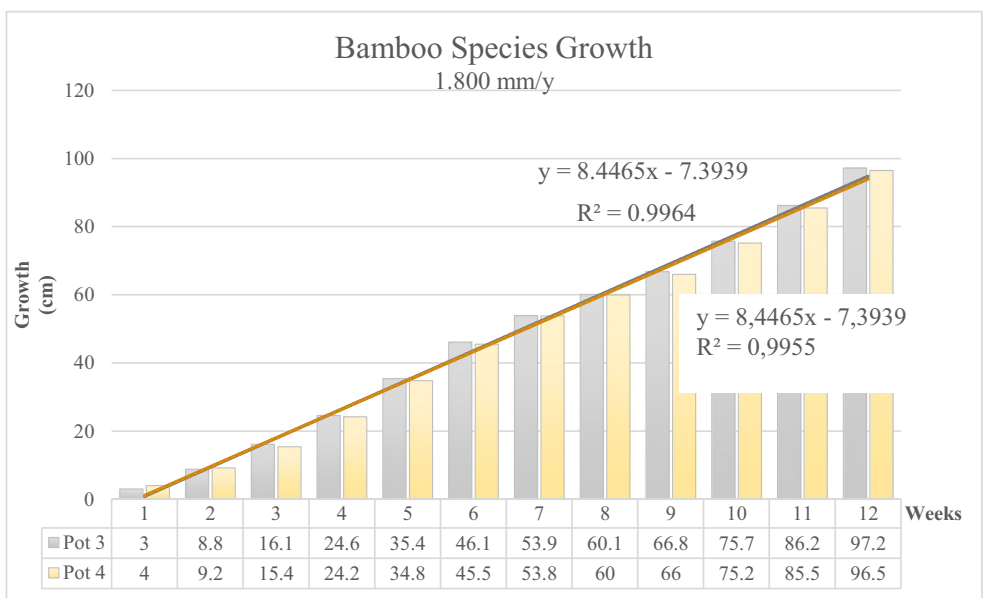




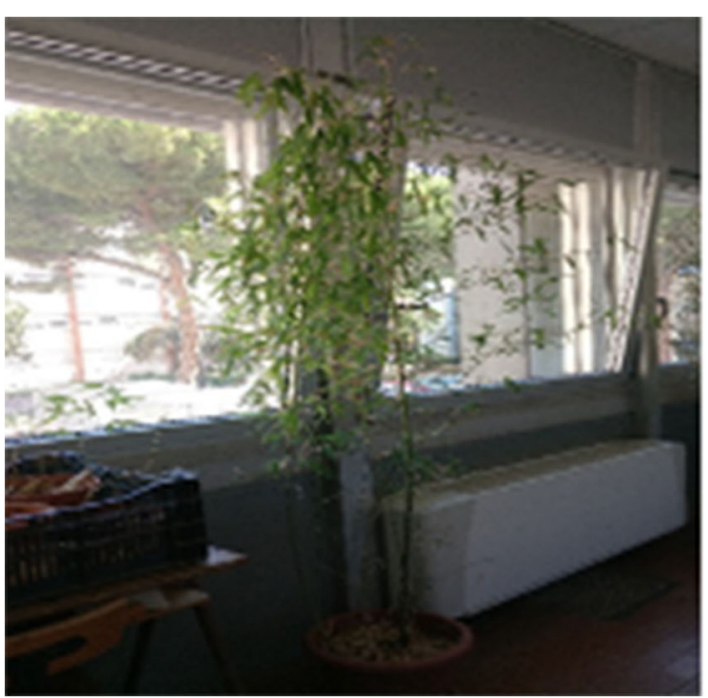

Fig. 7 Moso bamboo after first step of growth

To contaminate the soil of four pots, $\mathrm{K}_{2} \mathrm{Cr}_{2} \mathrm{O}_{7}$ was used in quantity apt to form an aqueous solution of $100 \mathrm{mg} \mathrm{Cr} / \mathrm{L}$ (APHA, AWWA 1998).

At the end of these tests, information obtained were the weekly growth rate for each plant during the test and the morphology of the plants after the contamination with the SEM that was used also to obtain information the quantity of chromium adsorbed by the morphological structures of the plant.

At the concentration of irrigation water $100 \mathrm{mg} \mathrm{Cr} / \mathrm{L}$, the $\mathrm{g}_{\mathrm{r}}$ was considerably reduced, but in both pots 1 and 2 , the bamboo plants still maintain his vegetative functions (Fig. 8). Only after 5 weeks in pot 2 a necrosis of the upper part of the stem and of the upper leaves has been showed, where the growth was almost zero, the better interpolation curve was $y=0.0038$ (weeks) $^{2}-$ 0.0655 (weeks) +55.13 with a low equal to $R^{2}=0.3862$.

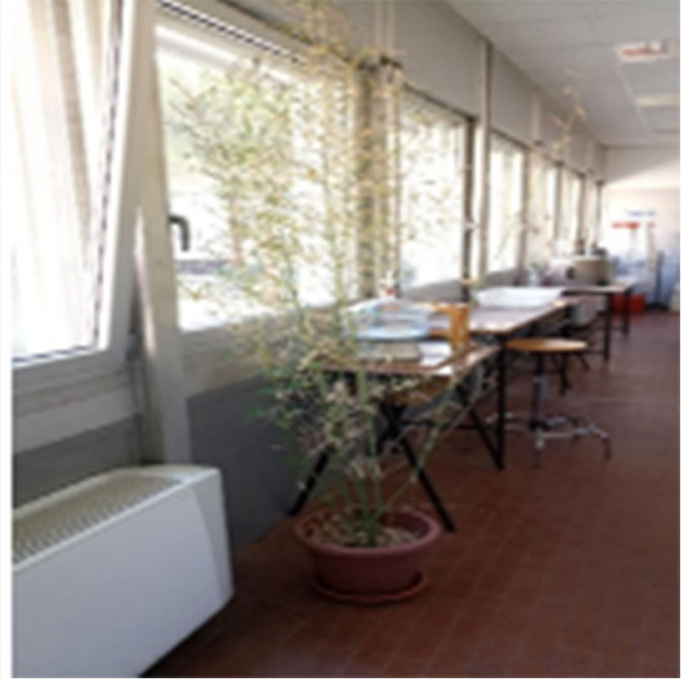

In first pot, the growth interpolation curve was $h=$ $56.45 \times e^{0.0062}$ (weeks). The slope of this curve (pot 1) was higher than in pot 2 due to the higher total tissue mass in the first pot.

Like in pots $1-2$, Moso bamboo in pots $3-4$, where the soil was contaminated with an aqueous solution of $100 \mathrm{mg} \mathrm{Cr} / \mathrm{L}$, does not show obvious symptoms of contamination stress (Fig. 9).

The tolerance for bamboo in pots 3 and 4 was higher and an higher $\mathrm{g}_{\mathrm{r}}$ has been also shown. The interpolation curve for pot 3 was $h=97.13 \times e^{0.0012}$ (weeks) with $R^{2}=0.978$. The interpolation curve for pot 4 was $h=$ $96.485 \times e^{0.0014}$ (weeks) with $R^{2}=0.935$.

Application of chromium caused some significant change in tissue morphological parameters after the fifth-sixth week, particularly in pot 3 where some tissue necrosis has been revealed due to the higher chromium
Fig. 8 Moso bamboo tolerance. Growth with $600 \mathrm{~mm} /$ year contaminated water. Pots $1-2$

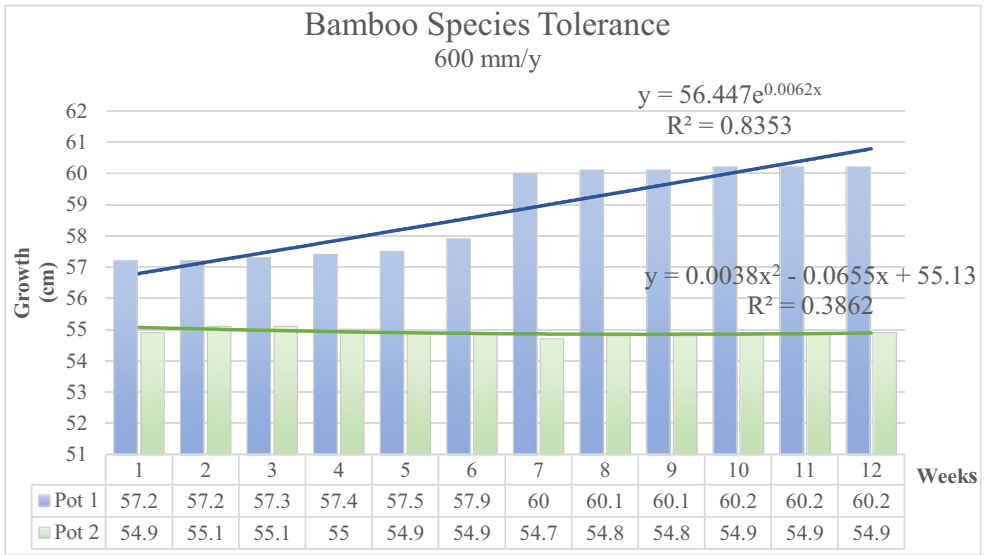


Fig. 9 Moso bamboo tolerance. Growth with $1.800 \mathrm{~mm} /$ year contaminated water. Pots 3-4

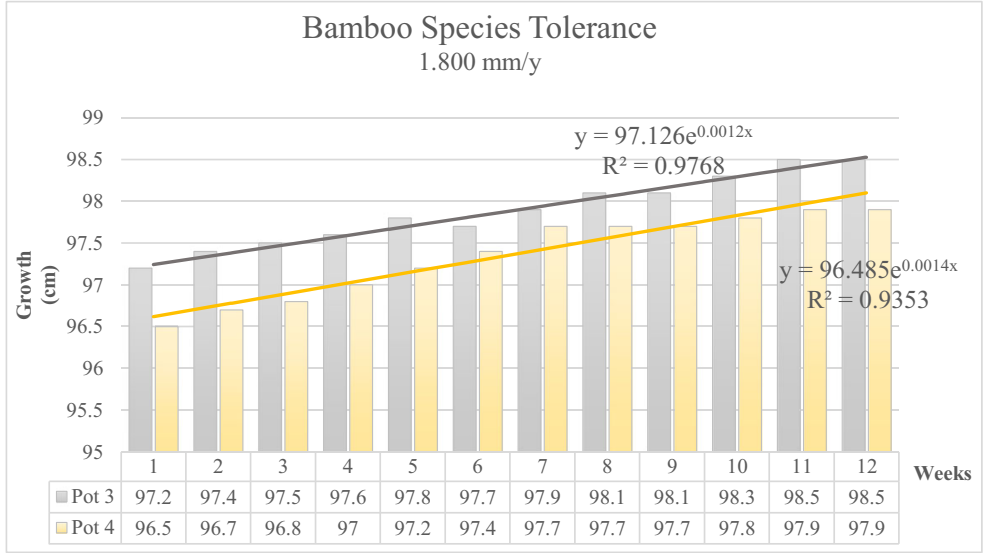

absorbed. These effects were more pronounced on roots and rhizomes than stem and leaves in terms of volume reduction, and reduction of the number of new shoots.

\subsection{Chromium Phytoextraction from the Soil}

Chromium phytoextraction depends on the specific hyperaccumulator-contaminant interaction ( $\mathrm{Tu}$ et al. 2004, López-Luna et al. 2009). Understanding mass balance analyses and the metabolic fate of pollutants in plants are the keys to proving the applicability of phytoremediation (Mwegoha 2008; Oliveira 2012; Ranieri et al. 2020). Previous contamination tests were also aimed to quantify how much chromium the Moso bamboo plant is able to retain. Plants use different mechanisms to control the toxic effects of chromium, accumulating it in the tissues through the uptake of the roots and subsequent translocation (Ranieri et al. 2020).

Figures 10 report the phytoextraction capacity of bamboo and the soil chromium content after 3 months for $600 \mathrm{~mm} /$ year pots and Figs. 12 for $1800 \mathrm{~mm} /$ year pots. The residual levels of $\mathrm{Cr}$ in the
Fig. 10 Moso bamboo phytoextraction. Growth with $600 \mathrm{~mm} /$ year contaminated water.

Pot 1

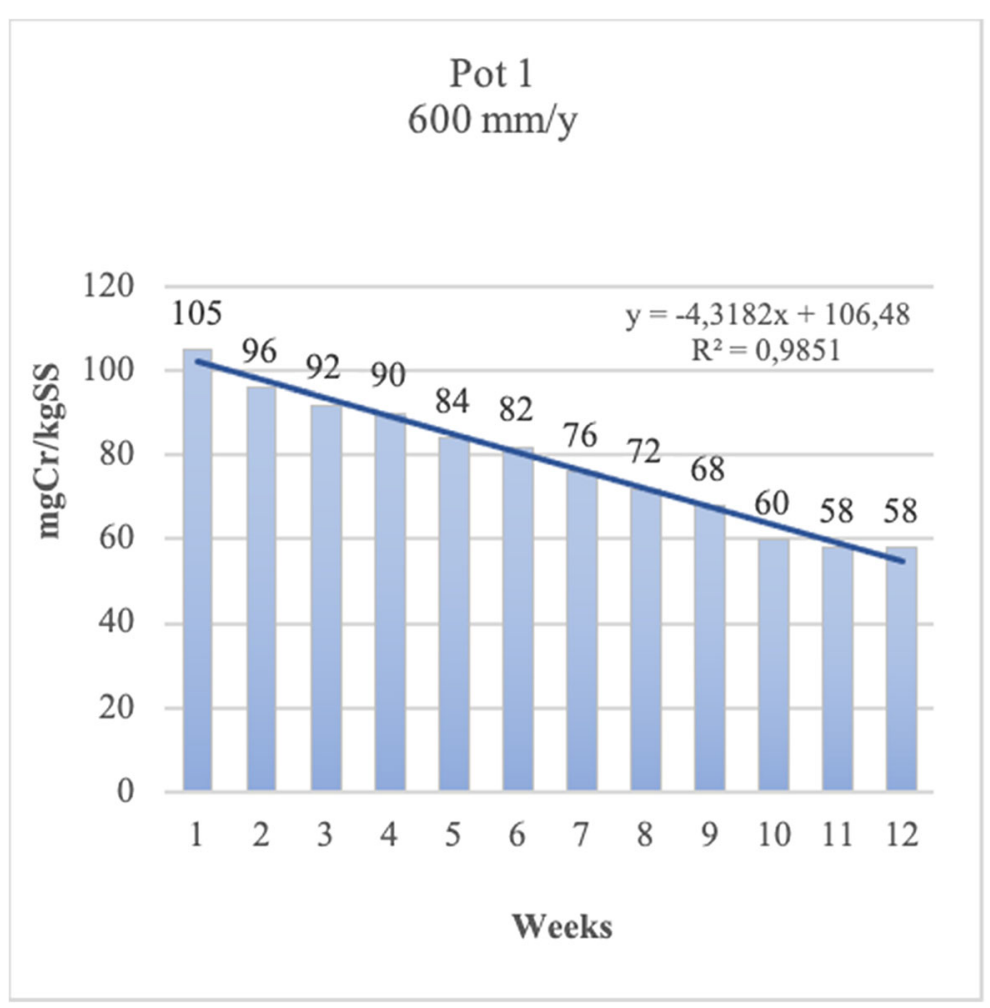


Fig. 11 Moso bamboo

phytoextraction. Growth with

$600 \mathrm{~mm} /$ year contaminated water.

Pot 2

soils after the experimentation ranged from 58 to $60 \mathrm{mg} / \mathrm{kg}$ DW for pots 1 and 2 (Figs. 10, 11), and from 156 to $162 \mathrm{mg} / \mathrm{kg} \mathrm{DW}$ for pots 3 and 4 (Figs. 12, 13). Results on soils analyses showed that the chromium levels reduced significantly after the
Pot 2

$600 \mathrm{~mm} / \mathrm{y}$

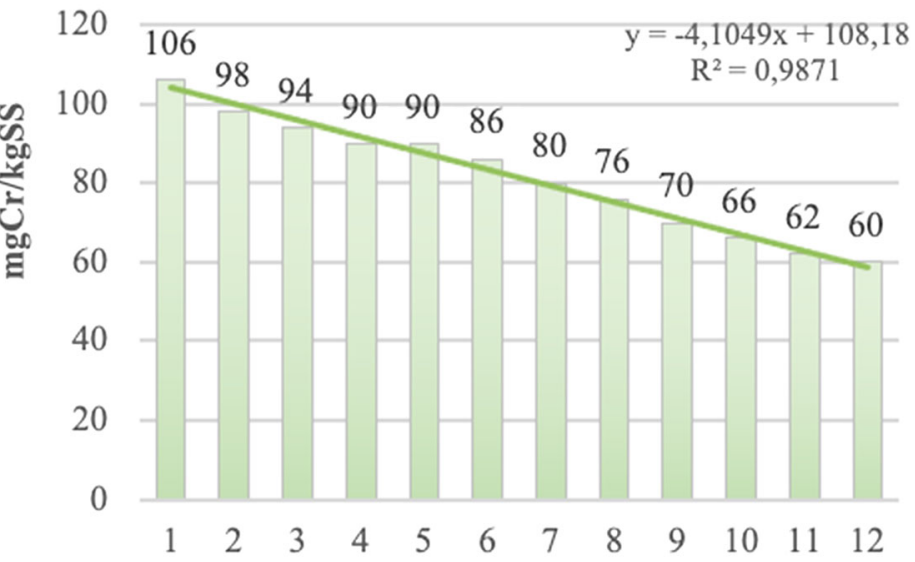

Weeks
Fig. 12 Moso bamboo phytoextraction. Growth with $1.800 \mathrm{~mm} /$ year contaminated water. Pot 3

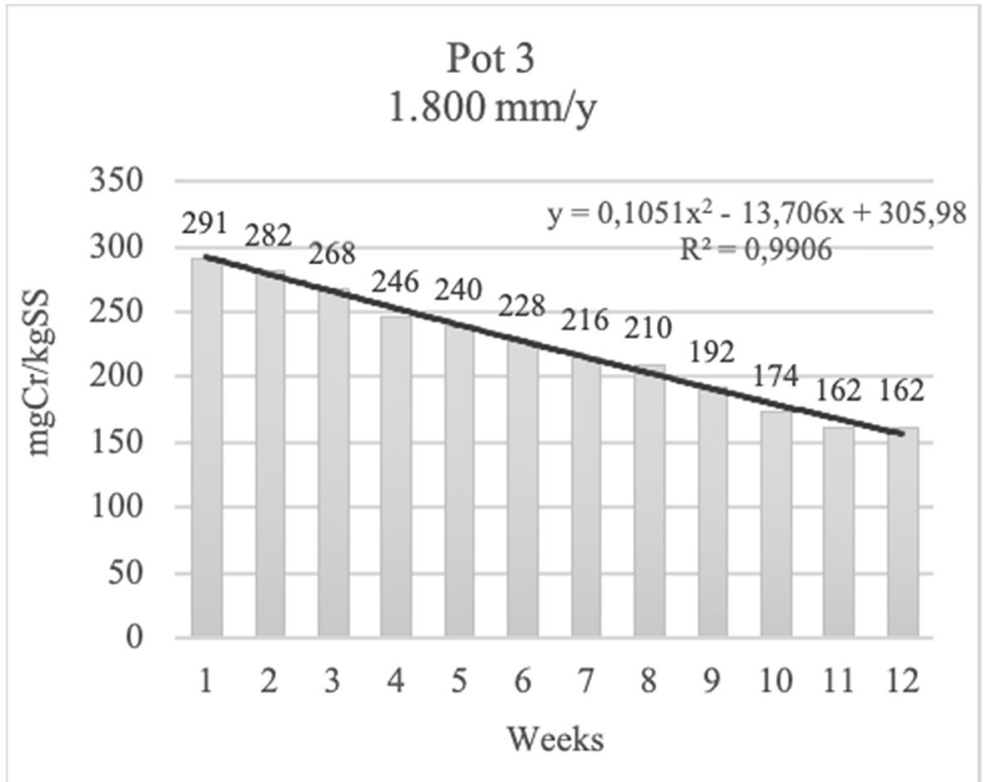

growing plants on contaminated soils with percentages of removal around $50 \%$ similar than in other experiences (Bosire 2014).

Chromium removal percentage from soil was ranging from 43.3 to $44.7 \%$ (pots 1 and 2) starting from a 
Fig. 13 Moso bamboo phytoextraction. Growth with $1.800 \mathrm{~mm} /$ year contaminated water. Pot 4

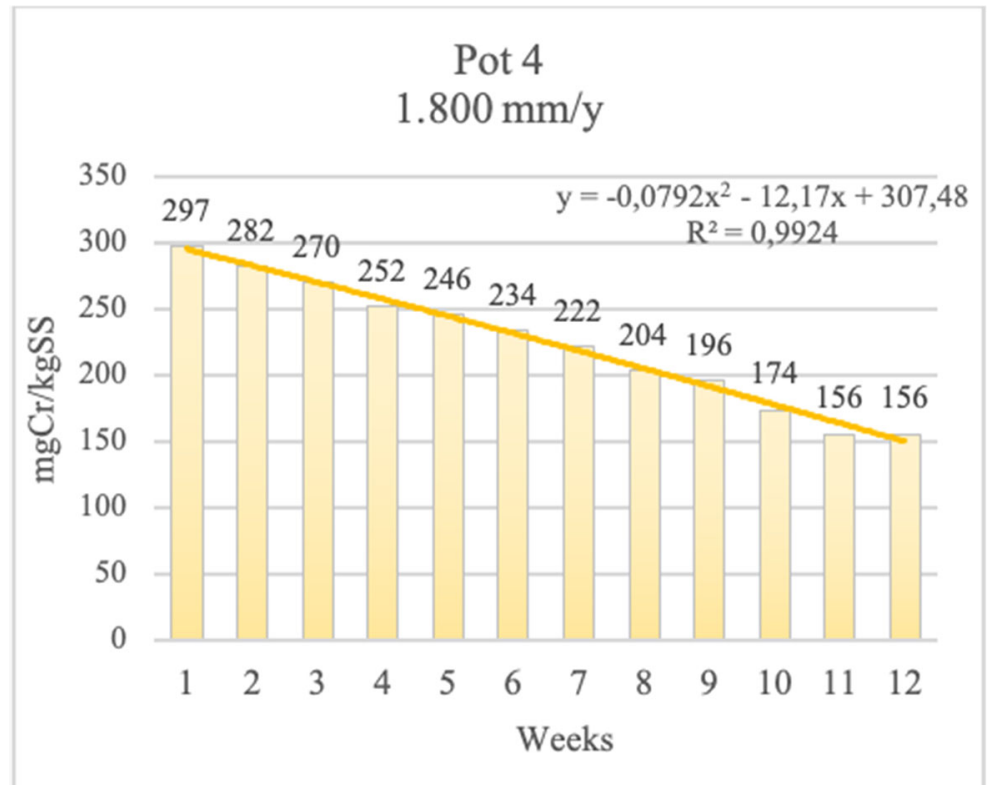

contamination of approx. $105 \mathrm{mg} / \mathrm{kg}$ DW and ranging from 44.3 to $47.5 \%$ (pots 3 and 4 ) starting from a contamination of approx. $295 \mathrm{mg} / \mathrm{kg} \mathrm{DW}$. The interpolating curve for pot 1 is $[\mathrm{Cr}]=110 \times e^{-0.056}$ (weeks) with
$R^{2}=0.982$ and for pot $2:[\mathrm{Cr}]=112 \times e^{-0.051}$ (weeks) with $R^{2}=0.981$. Pots 3-4 are, respectively, $[\mathrm{Cr}]=$ $0.10 \times(\text { week })^{2}-13.7$ (week) +306 with $R^{2}=0.99$ and $[\mathrm{Cr}]=0.08 \times(\text { week })^{2}-12.2($ week $)+307$ with $R^{2}=$
Fig. 14 Chromium (mg/L and $\%$ ) absorbed by elements of bamboo in pots $1-4$

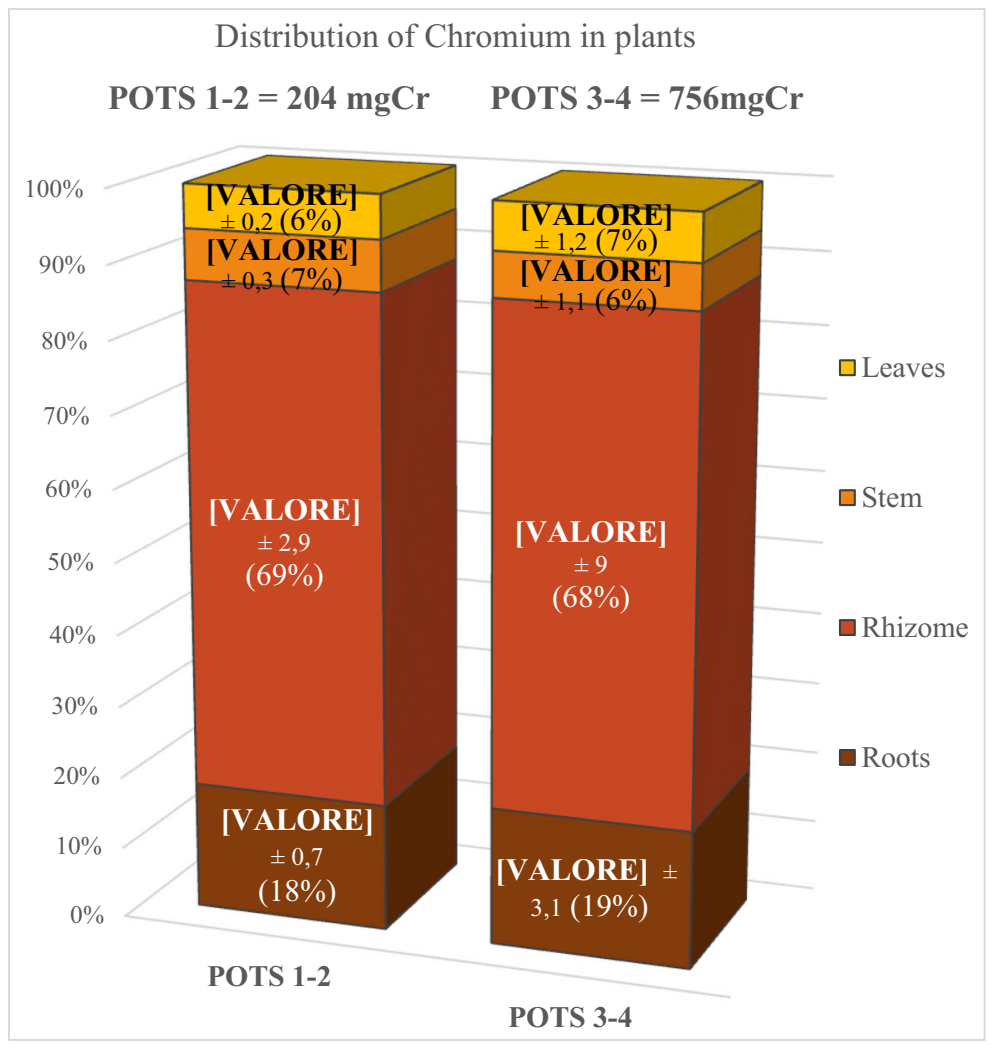


0.99 indicating an higher tendency to continue the phytoextraction vs time if compared to the $600 \mathrm{~mm} /$ year pots. Another noteworthy factor is the influence that the characteristics of the soil can have on the adsorption of chromium: if the soil has humic acids inside, the metal tends to form bonds with them as a matter of priority, reducing phytoextraction, as confirmed by numerous other studies (Salido et al. 2003; CarvalhoPereira et al. 2015), reducing its bioavailability up to 57\% (Cary 1982; Kalčíková et al. 2016).

\subsection{Chromium Distribution in Tissues}

Samples of the leaves and roots of the plants of the pots $1,2,3$, and 4 were taken, after the contamination test in order to perform SEM microanalyses on them to analyze the chromium distribution. For all pots, the aerial parts of the plant showed little chromium concentrations. This could indicate that 84 days of $\mathrm{Cr}$ poisoning is not enough to exceed the tolerance limit of the roots and rhizomes, thus allowing the translocation of the metal in the aerial part (Shanker Aruna et al. 2005; Shehata et al. 2019). Having found chromium principally in the roots and rhizomes, it is confirmed that Moso bamboo concentrates chromium in the rhizome-root system by limiting transport in the aerial parts, parts included in the animal and human food chain (Vernay et al. 2007; Gopal et al. 2009; Awalla 2013; Shahid et al. 2017). In Fig. 14, the distribution of the chromium in bamboo tissues is reported for pots $1-4$ : for pots $1-2,142 \mathrm{mg} \mathrm{Cr}$ is in the rhizomes, $36 \mathrm{mg} \mathrm{Cr}$ in the roots, $14 \mathrm{mg} \mathrm{Cr}$ in stems, and $12 \mathrm{mg} \mathrm{Cr}$ in the leaves that correspond to $69 \%$ for rhizomes, $18 \%$ for roots, $7 \%$ for stems, and $6 \%$ for leaves. Similar percentages of chromium distributions are revealed for pots 3-4, irrigated with $1800 \mathrm{~mm} /$ year, with a higher translocation rate and where the chromium in leaves was approx. 7\% (Fig. 14). Relating to the ratio of chromium mass retained per plant tissues mass, the quantity of chromium per gram of root/ rhizome is equal, as average, to $3.9 \mathrm{mg} / \mathrm{g} \mathrm{DW}$, while the quantity of chromium per gram of stem/leaves is equal, as average, to $2.5 \mathrm{mg} / \mathrm{g} \mathrm{DW}$.

\section{Conclusions}

Phytoextraction technique by Moso bamboo has showed a good adaptability in Mediterranean conditions and high performances in removal chromium from soil.
Conclusive remarks that should be drawn from the experience are:

- Moso bamboo has evidenced a good growth in lab conditions either for $600 \mathrm{~mm} /$ year condition with an average value equal to $4.56 \mathrm{~cm} /$ week either for $1800 \mathrm{~mm} /$ year conditions with an average value equal to $8.45 \mathrm{~cm} /$ week.

- The tolerance was tested for all pots containing bamboo plants; results have showed a good response of the plant up to $100 \mathrm{mg} \mathrm{Cr} / 1$ solution utilized for irrigation of the pots. During the 12week irrigation period, the growth rate of the bamboo in pots irrigated with the $600 \mathrm{~mm} / \mathrm{year}$ was almost zero in one pot and less than $1 \mathrm{~mm} /$ week in the other; the same rate, $1 \mathrm{~mm} /$ week, was shown in both bamboo pots irrigated with $1800 \mathrm{~mm} /$ year of contaminated water.

- Chromium removal percentages from soil were in 12 weeks quite high with values ranging from 43.3 to $44.7 \%$ starting from a contamination of approx. $105 \mathrm{mg} / \mathrm{kg}$ DW for $600 \mathrm{~mm} /$ year and ranging from 44.3 to $47.5 \%$ starting from a contamination of approx. $295 \mathrm{mg} / \mathrm{kg} \mathrm{DW}$ for $1800 \mathrm{~mm} /$ year.

- Inside the plant tissues, chromium was principally found in the rhizome, approx. $68 \%$, in all pots. Translocation rate was slightly higher for pots irrigated with $1800 \mathrm{~mm} /$ year where the chromium in leaves was approx. $7 \%$.

Acknowledgments The authors would like to Antonella Galati and Adriano Boghetich for their support in laboratory equipment and operation. The experimentation has been carried out under an agreement with the EU financed PON Project “Taranto," Dept. of Biology Task.

Funding Information Open access funding provided by Università degli Studi di Bari Aldo Moro within the CRUICARE Agreement.

\section{Compliance with Ethical Standards}

Conflict of Interest The authors declare that they have no conflict of interest.

Open Access This article is licensed under a Creative Commons Attribution 4.0 International License, which permits use, sharing, adaptation, distribution and reproduction in any medium or format, as long as you give appropriate credit to the original author(s) and 
the source, provide a link to the Creative Commons licence, and indicate if changes were made. The images or other third party material in this article are included in the article's Creative Commons licence, unless indicated otherwise in a credit line to the material. If material is not included in the article's Creative Commons licence and your intended use is not permitted by statutory regulation or exceeds the permitted use, you will need to obtain permission directly from the copyright holder. To view a copy of this licence, visit http://creativecommons.org/licenses/by/4.0/.

\section{References}

Al-Bataina, B. B., Young, T. M., \& Ranieri, E. (2016). Effects of compost age on the release of nutrients. International Soil and Water Conservation Research Journal, 4, 230-236.

Anderson, C., Moreno, F., \& Meech, J. (2005). A field demonstration of gold phytoextraction technology. Minerals Engineering, 18, 385-392.

APHA, AWWA, WEF (1998) Standard methods for the examination of water and wastewater. XX Ed. 4-21/4-23.

Arshad, M., Silvestre, J., Pinelli, E., Kallerhoff, J., Kaemmerer, M., Tarigo, A., et al. (2008). A field study of lead phytoextraction by various scented Pelargonium cultivars. Chemosphere, 71, 2187-2192.

Awalla, O. C. (2013). Phytoremediation of sewage sludge in soils contaminated with heavy metals. Global Journal of Environmental Sciences, 12, 13-19.

Bian, F., Zhong, Z., Zhang, X., \& Yang, C. (2017). Phytoremediation potential of moso bamboo (Phyllostachys pubescens) intercropped with Sedum plumbizincicola in metal-contaminated soil. Environmental Science and Pollution Research, 24, 27244-27253.

Bosire GO (2014) Rehabilitation and phytoremediation of heavy metal polluted riverine wetlands using bamboo for Phytoextraction in Kibera. Dissertation, Kenyatta University.

Carvalho-Pereira, T., De, T., Santos, S., Pestana, E., Souza, F., Souza, V., Gomes, B., Lage, B., Janaína, B., Nunesmaia, P., Thaís, S., Sena, E., Mariano-Neto, E., \& da Silva, E. (2015). Natural humic substances effects on the life history traits of Latonopsis australis SARS (Cladocera - Crustacea). Chemosphere, 120, 165-170.

Cary, E. E. (1982). Chromium in air, soils, and natural waters. In S. Langard (Ed.), Biological and environmental aspects of chromium, edn (pp. 49-63). New York: Elsevier Biomedical.

Chen, J., Shafi, M., Li, S., Wang, Y., Wu, J., Ye, Z., Peng, D., Yan, W., \& Liu, D. (2015a). Copper induced oxidative stresses, antioxidant responses and phytoremediation potential of Moso bamboo (Phyllostachys pubescens). Scientific Reports, 5, 13554.

Chen, J. R., Peng, D. L., Shafi, M., Li, S., Wu, J. S., Ye, Z. Q., Wang, Y., Yan, W. B., \& Liu, D. (2015b). Phytoremediation potential of Moso bamboo (Phyllostachys pubescens) for zinc and ultrastructure changes under zinc toxicity, ISSN 1067_4136. Russian Journal of Ecology, 46(5), 444-449.

Cho-Ruk, K., Kurukote, J., Supprung, P., \& Vetayasuporn, S. (2006). Perennial plants in the phytoremediation of leadcontaminated soils. Biotechnology, 5, 1-4.
Ciudin, R., Isarie, C., Cioca, L., Petrescu, V., Nederita, V., \& Ranieri, E. (2014). Vacuum waste collection system for an historical city centre. Scientific Bulletin, 76, 215-222.

Collin, B., Doelsch, E., Keller, C., Panfili, F., \& Meunier, J. D. (2013). Effects of silicon and copper on bamboo grown hydroponically. Environmental Science and Pollution Research, 20, 6482-6495.

Gardea-Torresdey, J. L., Peralta-Videa, J. R., Montes, M., de la Rosa, G., \& Corral-Diaz, B. (2004). Bioaccumulation of cadmium, chromium and copper by Convolvulus arvensis L.: Impact on plant growth and uptake of nutritional elements. Bioresource Technology, 92(3), 229-235.

Gikas, P., \& Ranieri, E. (2014). Effects of plants for reduction and removal of hexavalent chromium from a contaminated soil. Water, Air, and Soil Pollution, 225(6), 198.

Gopal, R., Rizvi, A. H., \& Nautiyal, N. (2009). Chromium alters iron nutrition and water relations of spinach. Journal of Plant Nutrition, 32(9), 1551-1559.

Kabata-Pendias, A., \& Pendias, H. (2001). Trace elements in the soil and plants (3rd ed.p. 413). Boca Raton: CRC Press.

Kalčíková, G., Zupančič, M., Jemec, A., \& Gotvajn, A. Ž. (2016). The impact of humic acid on chromium phytoextraction by aquatic macrophyte Lemna minor. Chemosphere, 147, 311317.

Karimi, N., Ghaderian, S. M., Raab, A., Feldmann, J., \& Meharg, A. (2009). An arsenic-accumulating, hypertolerant brassica, Isatis capadocica: Rapid report. The New Phytologist, 184, $41-47$.

Kigomo BN (2007) Guidelines for growing bamboo KEFRI guideline series: No. 4 Kenya Forestry Research Institute, Nairobi, Kenya.

Liu, D., Li, S., Islam, E., et al. (2015). Lead accumulation and tolerance of Moso bamboo (Phyllostachys pubescens) seedlings: Applications of phytoremediation. Journal of Zheijang University SCIENCE B - Biomedicine \& Biotechnology, 16(2), 123-130.

López-Luna, J., Gonzalez Chavez, M. C., Esparza García, F., \& Rodriguez Vazquez, R. (2009). Toxicity assessment of soil amended with tannery sludge, trivalent chromium and hexavalent chromium, using wheat, oat and sorghum plants. Journal of Hazardous Materials, 163, 829-834.

McGrath, S. P., Lombi, E., Gray, C. W., Caille, N., Dunham, S. J., \& Zhao, F. J. (2006). Field evaluation of $\mathrm{Cd}$ and $\mathrm{Zn}$ phytoextraction potential by the hyperaccumulators Thlaspi caerulescens and Arabidopsis helleri. Environmental Pollution, 141, 115-125.

Mississippi Watershed Management Organization (2014) Manual for turfgrass maintenance with reduced environmental impacts Version 2, Fortin Consulting Inc.

Mwegoha, W. J. S. (2008). The use of phytoremediation technology for abatement soil and groundwater pollution in Tanzania: Opportunities and challenges. Journal of Sustainable Development in Africa, 10(1), 140-156.

Oliveira, H. (2012). Chromium as an environmental pollutant: Insights on induced plant toxicity. Journal of Botany, 2012, 8.

Petrella, A., Petrella, M., Boghetich, G., Basile, T., Petruzzelli, V., $\&$ Petruzzelli, D. (2012). Heavy metals retention on recycled waste glass from solid wastes sorting operations: A comparative study among different metal species. Industrial and Engineering Chemistry Research, 51, 119-125. 
Petrella, A., Petruzzelli, V., Ranieri, E., Catalucci, V., \& Petruzzelli, D. (2016a). Sorption of Pb (II), Cd (II) and Ni (II) from single- and multimetal solutions by recycled waste porous glass. Chemical Engineering Communications, 203, 940-947.

Petrella, A., Mascolo, G., Murgolo, S., Ranieri, E., Petruzzelli, V., Spasiano, D., \& Petruzzelli, D. (2016b). Photocatalytic oxidation of organic micro-pollutants: Pilot plant investigation and mechanistic aspects of the degradation reaction. Chemical Engineering Communications, 203(10), 12981307.

Petrella, A., Spasiano, D., Acquafredda, P., De Vietro, N., Ranieri, E., Cosma, P., et al. (2018). Heavy metals retention (Pb(II), $\mathrm{Cd}(\mathrm{II}), \mathrm{Ni}(\mathrm{II})$ ) from single and multimetal solutions by natural biosorbents from the olive oil milling operations. Process Safety and Environmental Protection Journal, 114, 79-90.

Ragazzi, M., Rada, E. C., Ranieri, E., Masi, S., \& Montanaro, C. (2014). Critical analysis of the integration of residual municipal solid waste incineration and selective collection in two Italian tourist areas. Waste Management and Research, 32(6), 551-555.

Ranieri, E., \& Świetlik, J. (2010). DBPs control in European drinking water treatment plants using chlorine dioxide: Two case studies. Journal of Environmental Engineering and Landscape Management, 18(2), 85-91.

Ranieri, E., Fratino, U., Petruzzelli, D., \& Borges, A. C. (2013). A comparison between Phragmites australis and Helianthus annuus in chromium phytoextraction. Water, Air, and Soil Pollution, 224, 1465.

Ranieri, E., Moustakas, K., Barbafieri, M., Ranieri, A. C., HerreraMelián, J. A., Petrella, A., \& Tommasi, F. (2020). Phytoextraction technologies for mercury- and chromiumcontaminated soil: A review. Journal of Chemical Technology \& Biotechnology, 95, 317-327.

Reeves, R. D., \& Baker, A. J. M. (2009). Metal-accumulating plants. In I. Raskin \& B. D. Ensley (Eds.), Phytoremediation of toxic metals: Using plants to clean up the (Environment ed., pp. 193-229). New York: Wiley.

Robinson, B., Kim, N., Marchetti, M., Moni, C., Schroeter, L., van den Dijssel, C., Milne, G., \& Clothier, B. (2006). Arsenic hyperaccumulation by aquatic macrophytes in the Taupo Volcanic Zone, New Zealand. Environmental and Experimental Botany, 58(1-3), 206-215.

Salido, A. L., Hasty, K. L., Lim, J. M., \& Butcher, D. J. (2003) Phytoremediation of arsenic and lead in contaminated soil using Chinese Brake ferns (Pteris vittata) and Indian mustard (Brassica juncea). International Journal of Phytoremediation, 5(2), 89-103.

Shahid, M., Rafiq, S. S. M., Khalid, S., Bibi, I., Niazi, N. K., Dumat, C., et al. (2017). Chromium speciation, bioavailability, uptake, toxicity and detoxification in soil-plant system: A review. Chemosphere, 178, 513-533.
Shanker Arun, K. T., Cervantes, C., Loza-Taverac, H., \& Avudainayagam, S. (2005). Chromium toxicity in plants. Environment International, 31, 739-753.

Shehata, S. M., Badawy, R. K., \& Aboulsoud, Y. I. E. (2019). Phytoremediation of some heavy metals in contaminated soil. Bullettin of the National Research Center Journal, 43, 189.

Song, X., Peng, C., Zhou, G., et al. (2013). Climate warminginduced upward shift of Moso bamboo population on Tianmu Mountain, China. Journal of the Mountain Science, 10, 363-369.

Tangahu, B. V., Abdullah, S. R. S., Basri, H., Idris, M., Anuar, N., \& Mukhlisin, M. (2011). A review on heavy metals (As, $\mathrm{Pb}$, and $\mathrm{Hg}$ ) uptake by plants through phytoremediation. International Journal of Chemical Engineering, 2011, 93916131 pages.

Tu, S., Ma, L. Q., Fayiga, A. O., \& Zillioux, E. J. (2004). Phytoremediation of arsenic-contaminated groundwater by the arsenic hyperaccumulating fern Pteris vittata L. International Journal of Phytoremediation, 6(1), 35-47.

Vaiopoulou, E., \& Gikas, P. (2012). Effects of chromium on activated sludge and on the performance of wastewater treatment plants: A review. Water Research, 46(3), 549-570.

Vaiopoulou, E., \& Gikas, P. (2020). Regulations for chromium emissions to the aquatic environment in Europe and elsewhere. Chemosphere, 254, 126876.

Van Lienden, C., Shan, L., Rao, S., Ranieri, E., \& Young, T. M. (2010). Metals removal from stormwater by commercial and non-commercial granular activated carbons. Water Environment Research, 82(4), 351-356.

Vernay, P., Gauthier-Moussard, C., \& Hitmi, A. (2007). Interaction of bioaccumulation of heavy metal chromium with water relation, mineral nutrition and photosynthesis in developed leaves of Lolium perenne L. Chemosphere, 68(8), $1563-1575$

Vidayanti, V., Choesin, D., \& Iriawati, I. (2017). Phytoremediation of chromium: Distribution and speciation of chromium in Typha angustifolia. International Journal of Plant Biology, 8(1).

Were, F. H., Wafula, G. A., \& Wairungu, S. (2017). Phytoremediation using bamboo to reduce the risk of chromium exposure from a contaminated tannery site in Kenya. Journal of Health and Pollution, 7(16), 12-25.

Xu, Y., Wong, M., Yang, J., Ye, Z., Jiang, P., \& Zheng, S. (2011). Dynamics of carbon accumulation during the fast growth period of bamboo plant. The Botanical Review, 77, 287-295.

Publisher's Note Springer Nature remains neutral with regard to jurisdictional claims in published maps and institutional affiliations. 